\title{
Islamic (Partner) Accounting and its Comparison with International Financial Accounting Standards (IFRS)
}

\author{
Ekaterina Yu. Voronova ${ }^{1, *}$, Husan Sunatullaevich Umarov ${ }^{2}$ \\ ${ }^{1}$ Department of Accounting, Statistics and Auditing, Moscow State Institute of International Relations of the Ministry of Foreign \\ Affairs of the Russian Federation (MGIMO University), 76 Vernadsky Prospect, Moscow, 119454, Russian Federation \\ ${ }^{2}$ Moscow State Institute of International Relations of the Ministry of Foreign Affairs of the Russian Federation (MGIMO University), \\ 76 Vernadsky Prospect, Moscow, 119454, Russian Federation
}

Received January 24, 2021; Revised March 22, 2021; Accepted April 18, 2021

\section{Cite This Paper in the following Citation Styles}

(a): [1] Ekaterina Yu. Voronova, Husan Sunatullaevich Umarov, "Islamic (Partner) Accounting and its Comparison with International Financial Accounting Standards (IFRS), "Universal Journal of Accounting and Finance, Vol. 9, No. 2, pp. 267 - 274, 2021. DOI: 10.13189/ujaf.2021.090217.

(b): Ekaterina Yu. Voronova, Husan Sunatullaevich Umarov (2021). Islamic (Partner) Accounting and its Comparison with International Financial Accounting Standards (IFRS). Universal Journal of Accounting and Finance, 9(2), 267 274. DOI: 10.13189/ujaf.2021.090217.

Copyright $\mathrm{C} 2021$ by authors, all rights reserved. Authors agree that this article remains permanently open access under the terms of the Creative Commons Attribution License 4.0 International License

\begin{abstract}
Accounting information systems are evolving along with modern information technology, which opens up countless opportunities to expand the intellectual, scientific and professional potential, contributing to the culture and "language" of accounting, professional principles extend beyond one country. However, differences in national and regional accounting systems still persist and reflect not only a diversity of accounting policy views but also deeper structural differences rooted in legal, financial and social systems. The Islamic (partner) accounting model appears to be the least studied and, at the same time, the most different from other accounting models. The economy of Islamic states is an important part of the world economy, so Islamic and other companies operating or investing in an Islamic institutional environment have a direct interest in proper disclosure of accounting information. The major goal of the research is to find similarities and differences between the IFRS and Islamic banking and to prove that it's beneficial in the modern Islamic countries. In order to assess and compare the IFRS and the Islamic banking practices the authors used comparative analysis and empirical study of the major parts of the both accounting systems. The major findings include the proof of the positive role of Auditing Organization for Islamic Financial Institutions (AAOIFI) which develops norms of convergence of International financial accounting standards (IFRS) and AAOIFI, and the proof that Islamic
\end{abstract}

banking is based on the Sharia and Islamic ethics, but can be based on other principles that are not contrary to Sharia. The authors have come to a conclusion that zakat (religious tax for the poor and needy) is a positive social external effect, and that Islamic accounting is characterized by greater disclosure than traditional accounting.

Keywords Islamic (Partner) Accounting, International Economic Information System, Accounting and Auditing Organization for Islamic Financial Institutions (AAOIFI), Islamic Ethic, Accounting Principles, Zakat

\section{Introduction}

The accounting information system is a part of the economic information system of any organization and plays a leading role in planning, monitoring, organizing numerous activities, communication and motivation of personnel, being a resource for performing managerial functions [1]. It is the accounting information systems that provide stakeholders with the necessary information (in the form of accounting (financial), management (internal) reporting and reporting on sustainable development) which is the groundwork for making informed economic decisions of a financial and managerial nature, directed 
inward or outward, respectively [2].

An increasingly internationalized economic life, primarily in the business sphere, requires consideration of many accounting issues, both in the academic discipline and practical activity, with an emphasis on their international aspect [3]. We witnessed an emerging imperative to interpret, compare and audit the financial statements of organizations operating in different countries and regions. Internationally, professional accounting services are widely represented, such as an audit of financial statements, tax consulting, engineering, etc. Accounting information systems are evolving along with modern information technologies. The accounting information system has become an integral part of the international economic information system [4]. Thus, the efforts of several states to bring national accounting systems closer together and to smooth over differences between them are becoming increasingly evident [5].

However, differences in national and regional accounting systems persist and do not merely reflect a diversity of accounting policy views but reveal deeper structural disparities rooted down in legal, financial and social systems. The accounting models can now be listed as British American, Continental, South American (Latin American), Islamic (partner) and IFRS accounting, of which the Islamic (partner) model seems to be the most different from all the others, yet, at the same time, the least studied $[6,7]$.

The major goal of the research is to define the role of Islamic banking in the modern financial system, compared with the IFRS and justifying its positive role as a social institute in the states with Islam as a dominant religion.

The hypothesis of the research is that in the modern context the integration (convergence) of banking systems entails positive external effects. This hypothesis becomes possible provided that globalization offers both new opportunities and challenges, including the need to obtain fair and reliable information in the shortest possible time, hence necessitating unification of accounting systems. The research hypothesis was analyzed using comparative analysis methods and empirically proven.

Within the framework of the research, the main objective is to identify the differences between Islamic banking and IFRS-compliant accounting, highlight the advantages and disadvantages of Islamic banking and lay down proposals for its use in developing the social environment and entrepreneurial activities.

Key research findings include a comparison of the Islamic accounting model as an institution and IFRS, as well as proof of the hypothesis for the positive effects of the convergence of IFRS and other accounting systems as exemplified by Islamic banking.

\section{Literature Review}

This article is based on the works of domestic and foreign scholars in the field of Islamic accounting. The following scholars have devoted their works to the theory, methodology and practice of Islamic (partner) accounting: Abdul Rahman A.A., Achmad N.L, Baydon N., Basri Kh., Bosi M.A., Gritsishen D.A., DiVanna J.A., Kamla M., Maurer B., Mervin K.L., Mohamed A.M., Napier K., Trokic A., Umarov Kh.S., Halim H.F., Hamed S., Khamidullina Z.Ch., Shaari H., Shibli A. et al. Let us consider the most interesting of them in the context of the research topic.

As the non-conventional accounting systems appeared, the researches on them were conducted in such a manner, that there was no clear answer on whether this system is good or bad. For instance, Yiannoulis [8] demonstrated a tendency of earnings management in Hellenic companies, but gave no estimation of Hellenic accounting, Raza, Shah, and Khurshid [9] gave some empirical evidence on Islamic banking negative sides, but proposed no solutions etc.

One of the interesting studies on the Islamic banking as an institution is [10, p. 395], where the author raises the question of how effective the staff is in the context of Islamic banking. This research is all the more important for this work as it demonstrates the possibility of using a personal reference to God as a motive for law-abiding behavior in the financial sphere. Another study [11] Islamic business ethics and practices of Islamic banks: Perceptions of Islamic bank employees in Gulf cooperation countries and Malaysia) specifies the main features of Islamic banking but provides no comparative characteristics of the Islamic accounting model institutions versus IFRS. Our research raises another important topic and that is social inequality. The work [12] shows the impact of Islamic accounting on the solvability of this problem. However, the work does not directly compare social responsibility of companies in the Western practice with that of Islamic banking. [13] provides the basis for the ethical perception of the financial sphere; based on this article, we hypothesize that Islamic banking is more than just a financial and social institution, being a cultural and religious institution as well.

The research of the Islamic banking standards implementation and their influence on the financial system in Islamic countries was conducted in [14], where, based on the experience of Pakistan, the authors proved that the transfer to IPSAS standards in the country complied with all the requirements of the transparent accounting system.

In Russia, much attention is paid to the research of Islamic economics and finance, but there is a limited number of works devoted to Islamic accounting, which predetermined the need to conduct research on the role of Islamic (partner) accounting in the international system of economic information. 


\section{Methodology}

To prove or disprove this hypothesis, the authors conducted a comparative analysis of IFRS and Islamic banking as institutions at two levels - theoretical and practical.

The theoretical pillow is based on the comparison of Islamic banking principles with the IFRS and finding possible options for their conjugation through similar institutional mechanisms.

The practical pillow includes the analysis of the two major socioeconomic instruments analysis - zakat and nisab. The analysis was conducted based on the price of nisab and its current estimation.

In order to prove that Islamic banking has a high importance for the social and economic development of the countries, which have inherited Islamic traditions, the authors have conducted a comparative analysis of Islam banking and IFRS by the following criteria: source of law, accountability, ownership of financial assets, social responsibility, accounting operations, consideration of the society interests, information disclosure, transparency and reliability. These factors emerge from the characteristic of a sustainable accounting system [1]. In case Islamic banking is in line with all of them, it's a significant and sustainable social institute.

Following comparison findings, the authors prove that the Institute of Islamic banking has a broader institutional matrix, and therefore, integration of the banking accounting systems necessitates expanding IFRS institutional matrix.

\section{Results}

\subsection{Theoretical Aspects of Islamic Banking as an Institution}

Islamic accounting is "a system that generates financial information for shareholders and other stakeholders and allows them to be confident that the organization is functioning in accordance with the Islamic worldview and Sharia" [15].The presented definition, firstly, suggests a "technical" insight of accounting where accounting means a process that embraces collecting, evaluating and recording information, generating reports and reporting to potential users. Secondly, it emphasizes that accounting in Islamic society is based on the provisions of Sharia and Islamic ethics.

Islamic (partner) accounting as a subject of research is a constituent of international accounting and as such carries the idea that accounting cannot be considered sheerly as a practical discipline. Application of the institutional approach methodology [16] to research studies of Islamic (partner) accounting makes it possible to radically change the understanding of accounting, to realize that its role has expanded significantly and it has become an integral part of the social and economic life of society. Viewing accounting as a social and institutional practice allows embedding it into a broader institutional context (institutional environment).

It should be emphasized that it is not the business environment including suppliers, buyers, and competitors, but the institutional environment with its social, political, legal, and religious rules that is a subject matter in determining the economic activity of the organization. It is the institutional environment that directly impacts the formation, development and dissemination of accounting practices. In this case, as a rule, some dominant factor comes to the fore to impact the standards and guidelines of the accounting system. For the Islamic accounting model, such a dominant factor is religion.

Therefore, considering Islamic banking as an institution, and not as an accounting system, one should note that it includes social elements, cultural characteristics and national characteristics typical for the Islamic world countries. These characteristics include a ban to give and take interest, support for the poor, personal responsibility for offences committed before God, i.e., responsibility regardless of whether this offence was discovered by law enforcement agencies (monitoring, audit bodies) or not. This is the background to form an accounting system that is not merely framed by the financial regulations but is also guided by the personal qualities of the accountant and the religion. There are two main directions of the way the religious factor impacts accounting.

The first direction predetermines that Muslim accountants should base their actions on the ethical norms of Islam, which prescribe compliance with the standards and guidelines of Sharia, including a number of prohibitions (prohibition of paying or receiving interest; prohibition of the production and sale of alcohol and other products that lead to moral degradation; prohibition of illicit enrichment (speculation, manipulation of demand), etc.), as well as professional ethical principles, provided that they do not contradict Sharia [17].

The second direction involves, in addition to personal ethics, compliance with business ethics. Business is regulated by the "Halal-Haram code" (Quran terms where " halal means "lawful"," "acceptable", "permissible", "permitted", and "haram" means "illegal", "forbidden") [18], and compliance with the "adl" (justice) principle [19]. Due to these guidelines, a number of researchers qualify Islamic banking (accounting) as social accounting [20, p. 927], [21]. Islamic accounting, unlike Western accounting, is believed to serve a larger group of stakeholders, since it is associated with the interests of society as a whole, and does not serve the interests of certain groups [22, p. 2]. Another difference is that Western accounting provides information about economic events and transactions, measures resources in terms of assets and liabilities, and transmits this information through financial reports to users 
who usually rely on this information when they make investment decisions. Islamic accounting defines socio-economic events and operations in both financial and non-financial terms, and the information obtained is used to ensure that Islamic organizations adhere to Sharia and achieve the socio-economic goals promoted by Islam [23, p. 34].

Thus, in Islamic society, the development of accounting theory is based mostly on the guidelines of Sharia, but it can also be based on other standards that do not contradict Sharia. Accounting theory development can take place either by establishing goals based on the Islam teaching and considering these goals in connection with modern accounting thought, or vice versa, starting with the research of accounting theory in order to accept those ideas that are combined with Sharia. Islamic spiritual standards directly impact accounting policies and accounting principles.

First of all, this accounting principle is the principle of social responsibility. Islamic doctrine considers Allah to be the owner of all wealth and a man is the vicegerent and trustee of Allah. People have the right to use resources for profit, but they are responsible to Allah. In business, owners and management are obliged to make decisions and act in the interests of both the organization itself and society as a whole through the mechanism of social investment. In this context, responsibility is expanded to include the responsibility to society. It is important for any organization to interact with society in all acceptable ways and meet its expectations since failure to meet social expectations impacts negatively on further viability of the organization.

The closest to the principle of social responsibility in Islam is the principle of accountability. Muslims are not only responsible but also accountable to Allah. It should be noted that this approach differs significantly from the principle of accountability in Russian accounting where accountability means personal accountability of the accountant to the management and owners of the company and, to a certain extent, other stakeholders. One of the main tasks of Islamic accounting is to "provide fair information, and therefore ensure that religious duties such as paying zakat are fulfilled" [24, p. 210] (religious tax for the benefit of the poor and the needy). Preparation of financial statements that reflect the financial position of the company (balance sheet), the financial result of its activities (statement of financial results), etc., is not aimed only at providing stakeholders with the necessary information but also at determining the value of the property from which zakat is paid.

In other words, in Islamic accounting, accountability is carried out through the zakat mechanism. Paying zakat is seen as a religious duty and an act of submission to Allah that distinguishes zakat from the "ordinary" taxes paid to the state by all citizens (not by Muslims only).

The principle of enhanced disclosure of accounting information is common with any accounting model; however, since "in Islam, accounting is not only a commercial activity but a religious duty as well and, as the Quran emphasizes, Islamic management is sourced from the enhanced disclosure to facilitate informed decision-making" [25, p. 245]. Therefore, Islamic accounting is characterized by a greater disclosure of information compared to traditional accounting. This is because on top of the common information, the Islamic accounting system must supplement financial statements with information allowing the assessment of the organizational activities regarding Sharia compliance, whether socio-economic goals of the organization were achieved from an ethical point of view (for example, lest the organization was engaged in prohibited activities), or if it caused harm to society (e.g. pollution), etc.

Therefore, Islamic financial organizations "in addition to generally accepted reports publish additional reports: a report on changes in restricted investments, a report on the use of funds from the Zakat fund and a report on the use of Qardh al-hasan funds" [26]. Islamic banks invest depositor funds placed in special restricted investment accounts (subject to restrictions imposed by depositors). Zakat funds are usually distributed among those in need but they can also be used for charitable purposes (support of science, education, culture, religion, etc.). Qardh al-hasan funds are used to provide interest-free loans. An organization's revenue can also be split into "revenue from permitted activities" and "revenue from prohibited activities". Organizations are recommended to provide segment reporting for permitted and prohibited activities, separately. Such information would influence the decision-making of Muslim users but would be irrelevant to non-Muslim users.

Another important principle is the principle of materiality. Proper disclosure requires that accounting reports contain all material information. "Information is considered material if its absence or misrepresentation may affect the decisions of users" [27, p. 130]. That is why accounting reports include explanatory notes and, if need ed, additional material information. The most important feature of the Islamic accounting system is the disclosure of all material information to achieve true and fair calculations and, on its bases, making decisions accords with the faith.

Reliability is also required from the accounting system. In Russian accounting practice, reliability means compliance with legal regulations whereas in Islamic accounting it means compliance with Sharia and Islamic ethics. Accounting statements of Islamic organizations are considered reliable if the information provided in them allows Muslims to perform their religious duties, for example, correctly assess the size of zakat or help the poor in other ways. If accountants are honest in performing their duties and do not pursue their own interests, they must prepare complete and reliable accounting statements that reflect all material information.

Let's compare the main principles of the IFRS 
accounting institute and Islamic banking (Table 1).

Table 1. Main principles of the IFRS accounting institute and Islamic banking

\begin{tabular}{|c|c|c|}
\hline Parameter & IFRS & Islamic banking \\
\hline Source of law & $\begin{array}{c}\text { International } \\
\text { organizations, } \\
\text { state institutions } \\
\end{array}$ & $\begin{array}{c}\text { The Quran and other } \\
\text { religious material }\end{array}$ \\
\hline Accountability & $\begin{array}{c}\text { To Company } \\
\text { owner }\end{array}$ & To Allah \\
\hline $\begin{array}{c}\text { Owner of } \\
\text { financial assets }\end{array}$ & Company owner & Allah \\
\hline $\begin{array}{c}\text { Social } \\
\text { responsibility }\end{array}$ & $\begin{array}{l}\text { is formed as a part } \\
\text { of the company's } \\
\text { social policy }\end{array}$ & $\begin{array}{l}\text { is formed following } \\
\text { religious laws regardless } \\
\text { of the company's policy }\end{array}$ \\
\hline $\begin{array}{l}\text { Accounting } \\
\text { operations }\end{array}$ & $\begin{array}{l}\text { are permitted or } \\
\text { prohibited on the } \\
\text { basis of their } \\
\text { legality and } \\
\text { financial law }\end{array}$ & $\begin{array}{c}\text { are permitted or } \\
\text { prohibited on religious } \\
\text { grounds as well as on } \\
\text { the basis of financial } \\
\text { law }\end{array}$ \\
\hline $\begin{array}{l}\text { Consideration of } \\
\text { the society } \\
\text { interests }\end{array}$ & $\begin{array}{l}\text { As a part of the } \\
\text { company's social } \\
\text { program aimed at } \\
\text { acquiring } \\
\text { goodwill }\end{array}$ & $\begin{array}{l}\text { Within the Muslim's } \\
\text { responsibility to Allah, } \\
\text { it does not depend on the } \\
\text { company's goals }\end{array}$ \\
\hline $\begin{array}{l}\text { Information } \\
\text { disclosure }\end{array}$ & $\begin{array}{l}\text { Within the } \\
\text { required minimum }\end{array}$ & $\begin{array}{c}\text { As complete as possible, } \\
\text { necessary for } \\
\text { calculating zakat }\end{array}$ \\
\hline Transparency & $\begin{array}{l}\text { As required in } \\
\text { accordance with } \\
\text { the legislation }\end{array}$ & Largest \\
\hline Reliability & $\begin{array}{l}\text { Compliance with } \\
\text { legal requirements }\end{array}$ & Compliance with Sharia \\
\hline
\end{tabular}

Thus, a comparison of the results in Table 1 allows us to draw a number of conclusions. Firstly, the theoretical basis of Islamic accounting is narrower as it is not subject to change and is difficult to expand. Secondly, Islamic banking is not so much a financial practice as an element of the worldview which means that its use at the global level is possible only in geographies with institutions coherent with Islam. Third, Islamic accounting has a vital social implication, and therefore it is necessary to gradually introduce socially important practices into IFRS, first, on the voluntary, and later on the mandatory basis. This follows from the fact that the current understanding of corporate social responsibility is blurred and changes from region to region. Moreover, there is a system evolving that relates social responsibility directly to goodwill, i.e., worth of a company which devalues the social element in the company functioning.

\subsection{Practical Aspects of Islamic Banking as an Institution}

The economies of Islamic states are an important part of the global economy, therefore Islamic and other companies operating or investing in an Islamic institutional environment have a direct interest in proper disclosure of accounting information. In 1991, Accounting and Auditing Organization for Islamic Financial Institutions (AAOIFI)
[28] was established in Bahrain) (https://aaoifi.com/objectives/?lang=en) that develops and explains accounting standards for the Islamic banking products, converges International Financial Reporting Standards (IFRS) and AAOIFI and organizes discussions on current issues in the field of accounting. Currently, AAOIFI includes organizations from 45 countries [29, p. 2].

In terms of institutionalization, Islamic banking is becoming more and more defined which positively affects its applicability in the context of globalization, not only in Islamic countries but also in countries where the share of the Muslim population is traditionally high. Globalization makes us find general principles and common ground, as well as lead Islamic accounting to common accounting standards as accepted in the rest of the world, that is, to bring IFRS and Islamic banking closer together. This is also true for the other accounting models mentioned earlier. Aside from that, from a practical perspective, there are still a number of difficulties in Islamic banking that call for additional actions from the company and the financial regulator. One of the essential difficulties, which at the same time is a significant social benefit, is the zakat calculating principle.

Although Islamic accounting, as well as traditional accounting, implies monetary measurement of accounting objects, still, in the Islamic view, inflation questions the function of money as a unit of measure since money ceases to be an adequate unit of measure and a reliable store of value. Therefore, when calculating zakat, which is one of the five pillars of Islam, the taxable minimum (nișāb) is the cost of 85 grams of gold [30], which should be evaluated based on the value of gold on the international market. Nișāb draws a line between payers and receivers of zakat. Those items in the financial reporting that are included in the calculation of zakat are estimated at market value with a clear task of determining the amount of nișab. The amount that zakat is paid from is usually calculated on the basis of the net working capital or net current assets (current assets minus current liabilities) taking into account adjustments for individual items.

Zakat acts as a mechanism for distributing benefits, designed to bridge the gap between the rich and the poor [31]. This mechanism increases the purchasing power of the poor and should contribute to economic growth by increasing consumer spending and aggregate demand. If the amount of zakat collected is insufficient, Islamic states may impose a temporary tax on the rich, which is also viewed as a religious duty (farḍ al-kifāyah) and an additional accountability mechanism.

\section{Discussion}

The results achieved reveal the following trends:

1. The accounting information system is designed to provide users with true, timely and reliable 
information. Growing globalization as a political, economic, technological process and, accordingly, global competition translates the need for ever-faster information retrieval. Spreading around the world, accounting is evolving along with modern information technologies that open up countless opportunities for expanding intellectual, scientific and professional potential. Information technology will continue to contribute to the fact that the culture and "language" of accounting, professional principles will increasingly go beyond one country, which, in turn, will have a direct impact on the globalization of the accounting profession through cultural aspects.

2. The Islamic (partner) accounting model has a distinction of the religious factor that dominates the standards and principles of the accounting system. This fact confirms that accounting is not a "technical" discipline but an integral part of the economic and social life of society. Viewing accounting not as self-contained but as embedded in a wide institutional context (institutional environment), will contribute to a deeper understanding of such a phenomenon as accounting, its history, current state and development prospects.

3. Ethical standards and principles in the Islamic accounting model are strongly guided by the religious factor that impacts accounting in two ways. The first direction involves Muslim accountant compliance with the guidelines of personal ethics. One part of the accountant's Islamic ethical guidelines is based solely on Sharia (for example, legitimacy and faith-based behavior). The other part is compliant both with Sharia and the accounting profession (e.g., reliability, objectivity, professional competence, technical standards). The second direction involves, in addition to personal ethics, compliance with the business ethics. Ethical standards and principles in the Islamic accounting model tend to develop and strengthen which allows us to view Islamic accounting as social accounting.

4. A number of principles in the Islamic accounting model have certain characteristics following its exposure to religious factor. First of all, these principles are the principle of social responsibility, the principle of accountability, the principle of enhanced disclosure of accounting information, the principle of materiality, the principle of reliability. All resources available to a person are in the form of trust management [32]. Therefore, a person (and, of course, an organization), exploiting resources, must be responsible to Allah and accountable to him. Islamic accounting reports must contain all material information, be characterized by greater disclosure of information than traditional reports, and be reliable so that Muslims can make decisions in accordance with the faith and fulfil their religious duties on its basis.
5. In the Islamic accounting model, the purpose of preparing financial statements is not aimed only at providing stakeholders with the necessary information but also at determining the value of the property from which zakat is paid. Those items of financial statements that are included in the calculation of zakat are valued at market value with the clear task of determining the amount of nisab (taxable minimum). Such accounting principle as accountability is carried out through the mechanism of zakat, the payment of which is considered as a Muslim religious duty, which distinguishes zakat from "ordinary" taxes that are paid to the state by all citizens (not by Muslims only).

In the context of globalization, the identified trends indicate that in developing new IFRS principles, one has to account for the increasingly global role of Islamic banking, its important social role meaning that the further development of Islamic banking should also lead to convergence of banking accounting systems.

\section{Conclusions}

Accounting provides not only a set of methodologies and techniques for management functions such as planning, organizing, motivating, communicating and monitoring, but also the language in which organizational goals, procedures and principles are defined and described. Accounting has become the language of business and a part of the socio-cultural mechanism of the society that has significantly increased its importance. Accountants are responsible for generating reliable information for people and society to make economic decisions; when an individual fulfils his duties, the effect of this is transferred to the society. If the duty is performed properly, then the society benefits and vice versa.

The main institutional factor influencing the formation and development of the Islamic (partner) accounting model is religion. The main duty of Muslims is to serve Allah in all aspects of their activities, since Islam does not distinguish between secular and spiritual life. Accounting is conducted in accordance with the law of Islam (Sharia), the ethical standards of which have had a direct impact on the principles of accounting. The principles of enhanced disclosure, materiality, reliability, and adequacy of information in Islamic accounting are highlighted by the principles of accountability and responsibility that are emphasized in Islamic accounting. The information generated by the Islamic accounting system must be reliable, consistent, comparable over time, and, most importantly, confirm that the organization conducts its activities in accordance with Sharia law and fulfils its socio-economic duties.

Islamic banking accounting in the context of globalization is a serious factor affecting the IFRS 
development while international standards contribute to the modernization of Islamic banking. Assuming that the two accounting systems have a positive effect on each other, their convergence will have a positive effect on both systems.

\section{REFERENCES}

[1] B. Zyznarska-Dworczak. Sustainability Accounting-Cogniti ve and Conceptual Approach, Sustainability, Vol.12, No.23, 9936, 2020. https://doi.org/10.3390/su12239936

[2] F. Belfo, A. Trigo. Accounting Information Systems: Tradition and Future Directions, Procedia Technology, Vol.9, 536-546, 2013.

[3] C. Graham, D. Neu. Accounting for Globalization, 2003. https://ssrn.com/abstract $=467685$

[4] A. Bhimani, M. Bromwich. Management accounting in a digital and global economy: the interface of strategy, technology, and cost information. In Chapman, C. S., Cooper, D. J., Miller, P. (eds.), Accounting, Organizations, and Institutions: Essays in Honour of Anthony Hopwood, Oxford University Press, Oxford, UK, 2009, 85-111.

[5] A. Vanoli. National Accounting at the beginning of the 21st century: Wherefrom? Whereto? https://ec.europa.eu/eurostat /cros/system/files/p1-national_accounting_at_the_beginning _of the_21st_century.pdf

[6] P. E. Eromonsele. Accounting Models: A Conceptual Review, International Journal of Marketing \& Financial Management, Vol.5, No.5, 29-35, 2017. http://doi.org/10.52 81/zenodo.821844

[7] T. Andersson, E. Lee, G. Theodosopoulos, Y. Yin, C. Haslam. Accounting for the financialized UK and US national business model, Critical Perspectives on Accounting, Vol. 25, 78-91, 2014.

[8] Y. Yiannoulis. Literature Review on the Hellenic Auditing and Accounting Environment before, during and after the Crisis Period, Universal Journal of Accounting and Finance, Vol.7, No.2, 43-49, 2019. DOI: 10.13189/ujaf.2019.070202

[9] M. W. Raza, S. F. Shah, M. R. Khurshid. Islamic Banking Controversies and Challenges. Interdisciplinary Journal of Contemporary Research in Business, Vol. 03, No. 10, 1018-1026, 2011.

[10] H. Yas, A. Mardani, A. Alfarttoosi. The Major Issues Facing Staff in Islamic Banking Industry and its Impact on Productivity, Contemporary Economics, Vol.14, No.3, 392-405, 2020.

[11] M. A. Musa, M. E. A. Sukor, M. N. Ismail, M. R. F. Elias. Islamic business ethics and practices of Islamic banks: Perceptions of Islamic bank employees in Gulf cooperation countries and Malaysia", Journal of Islamic Accounting and Business Research, Vol.11, No.5, 1009-1031, 2020. https://doi.org/10.1108/JIABR-07-2016-0080

[12] N. M. Mohamad, T. A. Masron, R. Wijayanti, M. M. Jamil. Islamic banking and income inequality: The role of corporate social responsibility, Journal Ekonomi Malaysia, Vol.52, No.2, 1-14, 2020. https://dx.doi.org/10.17576/JEM-2020-54 02-07

[13] S. V. Shamsudheen, S, Azhar Rosly. Towards development and validation of scale for ethical decision-making model in marketing: A religious-humanistic approach with special reference to ethical philosophy in Islam, Journal of Islamic Marketing, Vol.10, No.3, 928-947, 2020. https://doi.org/10. 1108/JIMA-07-2019-0143

[14] J. Miraj, W. Zhuqua. Analysis of Accounting Reforms in the Public Sector of Pakistan and Adoption of Cash Basis IPSAS, Universal Journal of Accounting and Finance, Vol.6, No.2, 47-53, 2018. DOI: 10.13189/ujaf.2018.060203

[15] N. L. Achmad, H. Achmed, W.S. Wan Mustafa. The Significance of Islamic Ethics to Quality Accounting Practice, International Journal of Academic Research in Business and Social Science, Vol.7, No.10, 693-703, 2017.

[16] D. M. Sadek, Z. Abas, K. Abd Rahim, A. Anuar, M. A. Abd Rahim. The Practices of Corporate Governance and Shariah Governance in Islamic Financial Institutions. In: I. Saidon, R. Said (eds.) Ethics, Governance and Risk Management in Organizations. Accounting, Finance, Sustainability, Governance \& Fraud: Theory and Application (pp. 131-147), Springer, Singapore, 2020.

[17] M. Farooq, N. El-Ghattis. In Search of the Sharīah, Arab Law Quarterly, Vol.32, No.4, 315-354, 2018.

[18] M. Luthfi Hamidi, A. Worthington. Islamic social banking: The way forward perbankan sosial Islam: Langkah kehadapan? Jurnal Ekonomi Malaysia, Vol.52, No.1, 195-207, 2018

[19]Z. F. Mamedov. Models of İslamic Banking: New Trends and Challenges for the Cis Countries Investment, Financial and Management Analysis, Vol.4, No.1, 125-133, 2017.

[20]R. Kamla. Critical insights into contemporary Islamic accounting, Critical Perspectives on Accounting, No.20, 921-932, 2009

[21] A. K. Putri, E. Fitriyanti, I. Sulistiana, I. Fahria, Hidayati. The effect of Islamic social reporting index on Islamic banking financial performance in Indonesia, Humanities \& Social Sciences Reviews, Vol.7, No.4, 609-616, 2019. https://doi.org/10.18510/hssr.2019.7481

[22] A. Trokic. Islamic Accounting; History, Development and Prospects, European Journal of Islamic Finance, No.3, 1-5, 2015.

[23]H. A. Halim. Understanding and Awareness of Islamic Accounting: The Case of Malaysian Accounting Undergraduates, International Journal of Academic Research in Accounting, Finance and Management Sciences, Vol.7, No.4, 33-39, 2017.

[24]H. Basri, A. K. Sity Nabiha, M. Shabri Abd. Majid. Accounting and Accountability in Religious Organizations: An Islamic Contemporary Scholar's Perspective, Gadiah Mada International Journal of Business, Vol.18, No.2, 207-230, 2016.

[25]A. Shibly. Conventional and Islamic Perspective in Accounting: Potential for Alternative Reporting Framework, International Journal of Economics and Management 
Engineering, Vol.12, No.2, 244-247, 2018.

[26] Kh. S. Umarov. The influence of confessional institutions on the provision of financial statements, International accounting, Vol.9, No.459, 983-992, 2019.

[27] G. V. Ulina, D. S. Ulin. Management accounting information system, Modern accounting and audit: theory, practice, development prospects: materials of the scientific and practical conference, May 1-30, 2014, Moscow, Russia, 129-133, 2014.

[28] AAOIFI. Accounting, Auditing and Governance Standards for Islamic Financial Institutions, Accounting and Auditing Organization for Islamic Financial Institutions, Manama, Bahrain, 2010, 809 p.

[29]A. M. Mohammed. Determinants of Implementation of Accounting Standards for Islamic Financial Institutions in
Iraq: A Conceptual Framework, Academy of Accounting and Financial Studies Journal, Vol.22, Sp., 1-6, 2018.

[30] A. K. Aljabr, A. M. Almousa, M. N. Mumtaz Bhutta, M. W. Alesmael, Q. M. Ilyas. An Expert System for Calculating Zakat in Islam, 2018 3rd International Conference on Emerging Trends in Engineering, Sciences and Technology (ICEEST), December 21-22, 2018, Karachi, Pakistan, 1-6, 2018. https://doi.org/10.1109/ICEEST.2018.8643319

[31] Y. Aziz, F. Mansor, Sh. Waqar, L. H. Abdullah, L. H. Abdullah. The nexus between zakat and poverty reduction, is the effective utilization of zakat necessary for achieving SDGs: A multidimensional poverty index approach, Asian Social Work and Policy Review, Vol.14, No.3, 1-13, 2020.

[32] A. Lekpek. Corporate social responsibility in islamic banking: Theory and practice, Sociologija, Vol.61, No.1, 32-54, 2019. https://doi.org/10.2298/SOC1901032A 